MADDISON, W.P., M.J. Donoghue \& D.R. MADdison. 1984 Outgroup analysis and parsimony, Systematic Zoology 33: 83-103

MANN, J. 1969. Cactus-feeding insects and mites. Washington (DC): US National Museum. Bulletin 256.

PElHAM, W.N. 1963. A thousand years of cochineal: a lost but traditional Mexican industry is on its way back, American Dyestuff Reporter 52: 53-61.

PÉRLZ GIUERA, G. \& M. KoszTARAR. 1992. Biosystematics of the family Dactylopiidae (Homoptera: Coccinea) with emphasis on the life cycle of Dactylopius coccus Costa. Studies on the morphology and systematics of scale in- sects N 16. Blacksburg (VA): Virginia Agricultural Experimental Station. VAES Bulletin 92 .

Saltzman, M. 1992. Identifying dyes in textiles, Americon Scientist 80: 474-81.

SwOFlORD, D.L. 1993. PAUP 3.1. Phylogenetic analysis using parsimony. Distributed by Illinois Natural History Museum.

WOLTLRS, B. 1999. Dispersion and ethnobotany of the cacas tree and other amerindian crop plants, Joumal of Applied Botany 73: 128-37.

YACOVLEFE, E. \& I. C. Mutelle. 1934. Notas al trabajo Colorantes de Paracas', Revista del Museo Nacional del Perti 3: 157-63.
References for TABLES

AQuINo, G. 1990 . Estudio cromosómico de cuatro tipos de cochinilla (Dactylopius spp.) (Homoptera : Dactylopiidae) del nopal. MSc thesis, Colegio de Postgraduados, México.

DE HAKO, M. 1996. Morfología de formas inmaduras y adultos de Dactylopius ceylonicus (Homoptera, Dactylopiidae), Revista de la Sociedad Entomológica Argentina 55: 17988.

DE HARO, M. \& L. CLAPS. 1995. Conociendo nuestra fauna III: Familia Dactylopiidae (Insecta: Homoptera): morfología, biología e importancia económica. Tucumán (Argentina): Universidad Nacional de Tucumán, Instituto Miguel Lillo. Serie Monográfica y Didáctica 19.

GilREATH, M.E. \& J.W. SMITH. 1985. Bionomics of Dactylopius confusus (Homoptera: Dactylopiidae), Annals of the Entomological Society of America 80: 768-74.

MANN, J. 1969. Cactus-feeding insects and mites. Washington (DC): US National Museum. Bulletin 256.

MARIN, R. \& V. CISNEROS. 1977. Biología y morfología de la coshinilla del carmin, Dactylopius roccus Costa (Homoptera: Dactylopiidae), Revista peruana de Entomología 20: 115-20.

Montiel, M.L. 1995. Morfología de Dactylopius coccus Costa (Homoptera: Dactylopidae), y su biología y producción en dos fotoperíndos. MSc thesis, Colegio de Postgraduados, México.

Moran, V.C. \& B.S. COBBY. 1979. On the life-history and fecundity of the cochineal insect, Dactylopius austrimus De Lotto (Homoptera: Dactylopiidae), a biological control agent for the cactus Opuntia aurantiaca, Bulletin of Entomological Research 69: 629-36.

PÉrez Guerra, G. \& M. Kosztará. 1992. Biosystematics of the family Dactylopiidae (Homoptera: Coccinea) with emphasis on the life cycle of Dactylopius cocrus Costa. Studies on the morphology and systematics of scale insects $N$ 16. Blacksburg (VA): Virginia Agricultural Experimental Station. VAES Bulletin 92.

\title{
D-Day sites in England: an assessment
}

\section{JOHN SCHOFIELD*}

Between midnight on 6 June (D-Day) and 30 June 1944, over 850,000 men landed on the invasion beach heads of Normandy, together with nearly 150,000 vehicles and 570,000 tons of supplies. Assembled in camps and transit areas over the preceding months, this force was dispatched from a string of sites along Britain's coastline between East Anglia and South Wales (Dobinson 1996: 2). The article reviews those sites in England involved in this embarkation. English Heritage's Monuments Protection Programme (MPP) aims to identify surviving sites and recommend appropriate protection for them.

Key-words: D-Day archaeology, Monument Protection Programme, Normandy, differential preservation, heritage

This paper describes those monuments surviving in England which represent the preparations and embarkation for the Normandy invasions of 1944 (see Dobinson et al. 1997 for a summary of the wider project of which this study forms a part). Contrary to what has been said previously (e.g. Wills 1994), much of this archaeological record does survive including examples of all types of site constructed or adapted to serve Operation Neptune - the assault phase of Overlord - which represented the springboard for the Allied invasion of Ger-

* Monuments Protection Programme, English Heritage, 23 Savile Row, London w1x 1AB, England.

john.schofield@english-heritage.org.uk

Received 1 August 2000, accepted 11 September 2000, revised 18 September 2000

ANTIQUITY 75 (2001): 77-83 
man-occupied Europe. However, there are variations in the quality and extent of survival. Some classes of monument are characterized more by ephemeral remains (camp sites, training facilities); other classes survive in more substantial form. These include: construction sites for the artificial concrete 'mulberry' harbours, and some components of the harbours themselves; repair, maintenance and construction sites for the many vessels involved in the Operation; and the embarkation sites from which troops departed and matériel was despatched for the French coast. It is these most obvious and substantial of remains that form the basis of this assessment, though accepting that examples of other monument classes do survive. For bombing decoys, put in place to confuse enemy reconnaissance, assessment has already been completed (Dobinson 2000: 177ff), while some work has been undertaken on surviving storage and supply depots (e.g. Francis 1997), on sites associated with PLUTO - the 'Pipeline under the Ocean' (Searle 1995), as well as by English Heritage on training areas and airfields.

\section{Preparations and embarkation}

Those monument classes representing the three principal aspects - or 'teeth' - of the Operation display some of the most obvious and monumental remains, symbolizing the scale and international significance of the events of June 1944. The three classes can be characterized in the following terms:

\section{Mulberry harbour construction sites}

The construction of the two artificial 'mulberry' harbours, built in sections (and different component parts generally at separate sites) and towed across the channel for disembarkation of troops and landing of supplies, was, in Churchill's words, 'a principal part of the great plan', and was decisive in the first days of the invasion. Although one harbour failed, the remaining structure - at Arromanches - was significant in providing the tactical advantage of surprise, and the logistical advantage of not having to land on a defended shore and at the mercy of the weather. Some components of the harbours were clearly surplus to requirements and remained in the UK; some sank on route, or were 'beached' for other reasons. Many sites were involved in this construction process, stretching at least from Southampton, via south coast ports and London, to the northeast.
Mulberry harbour construction sites were designed variously for the manufacture of: Phoenix caissons (partly submerged breakwaters made of cement; the largest was 60,447 tons) and Bombardons (floating steel breakwaters; up to 1000 tons) which made up the outer harbour, and the pierheads (Spuds), floating piers (Whales) with their steel-spanned roadways, and pontoons (Beetles), some of steel, some of concrete, that supported them (Harris 1994; Hughes 1994). These construction sites were located either in largely unmodified dry docks or slipways, or in excavated basins or on beaches. Much use was made of existing facilities. In Southampton, No. 5 Dry Dock and adjacent wet berths were used to build 12 of the largest Phoenix caissons, while Bombardons were assembled in No. 7 Dry Dock and on adjacent quays and land, the parts coming from all over the country (see Peckham 1994: 13-17 for photos). It is the beach construction sites, however, that retain most evidence for this construction task (e.g. Lepe, Stokes Bay and Hayling Island, all Hampshire), comprising construction platforms, slipways and winch-house foundations (Hughes 1994). One example of an excavated basin is at Clobb Copse, on the Beaulieu river, Hampshire (Cunningham 1994: 18), used for the construction of a Bombardon breakwater and 50 of the 470 Beetles constructed for Overlord. At Marchwood military port near Southampton, Beetle and Whale units were assembled on rail tracks and moved using a traverser or turntable. This traverser survives within the modern port. Some of the components built for the harbours also survive, mostly at sea, having sunk while on tow (e.g. Phoenix caissons in Portland and Langstone Harbours, and near Southend) but occasionally on land, as with the line of 36 Beetles at Dibden Bay (Hampshire). Sunken mulberry debris has been noted by recreational divers at various locations off the south coast (McDonald 1989; 1994; Pritchard \& McDonald 1991). Of course, parts of the mulberry harbour at Arromanches survive in situ.

\section{Maintenance and repair areas}

The maintenance and repair areas, and harbours used for landing craft and landing ship construction, were essential to developing and retaining a fleet capable of delivering Churchill's 'great plan'. With so many vessels involved (landing craft and landing ships principally, 
FIGURE 1. Gridirons at Lower Noss on the River Dart, Devon, photographed at low tide. (Photo J. Schofield.)

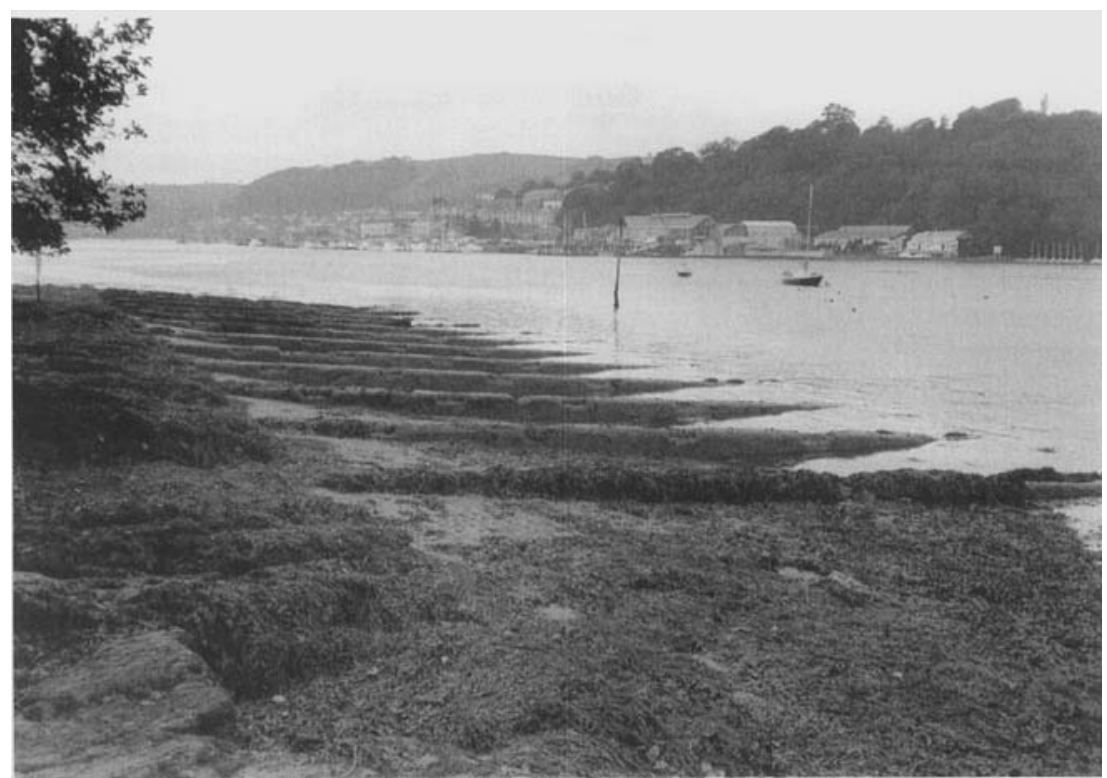

but there were 46 different types of vessel in all), maintenance was a significant task. Contemporary descriptions talk of unprecedented levels of maritime activity, with every port, harbour and boatyard being involved, in addition to beaches, on specially built slipways and gridirons, and in the streets of coastal towns and villages.

The purpose-built gridirons (also known as 'scrubbing grids') were used for maintenance, and took the form of a series of parallel concrete rails running down a slight gradient into the water, allowing a boat to be floated on at high tide, and repaired at low tide; some were supplied with a winch mechanism for pulling vessels onto the grid, and timber and steel mooring points ('dolphins') for securing them when afloat. Recorded examples are confined to the Rivers Dart (Devon), Tamar and Fal (Cornwall) and Portsmouth Harbour. At Lower Noss on the River Dart, one example survives with two sets of gridirons (FIGURE 1), each with concrete mooring posts, and steps leading up the river cliff behind to a levelled area with hutting and metal racks, presumably representing workshops. At another site, Mylor in Cornwall, archaeological evaluation has shown that part of this gridiron at least sits on a concrete raft, while the testimonies of those involved suggest that the shuttered concrete rails each supported a securely fixed timber rail on to which the boats were hauled (Watt forthcoming).
Repair areas in the form of slipways, with a metal rail, winch mechanisms and dolphins, are known to have been used for landing ship repairs. Examples survive at Mill Bay (near Salcombe) and Waddeton (both Devon). The Mill Bay example is particularly well preserved (FIGURE 2), and has the benefit of appearing in contemporary photographs with a landing ship in situ (Murch et al. 1994: 9). However, much of the repair and maintenance activity was conducted on an ad hoc arrangement and leaves little trace: for example, landing craft (assault) - LCAs - were small vessels constructed and repaired mainly in back streets and improvised hards at the water's edge.

\section{Embarkation sites}

Embarkation sites had to be well-designed and well-built if embarkation was to be a rapid and efficient exercise. Geographically the sites had to have access to hinterlands in which large numbers of troops and supplies could be concealed from enemy reconnaissance, yet which had the road and rail networks to allow their easy movement at the time of departure. This part of the Operation was planned well in advance, with most embarkation hards built in the period October 1942-spring 1943. In all, 68 embarkation sites are documented in public records (Dobinson 1996), representing those built specifically to serve general cross-Channel operations from 1942 onwards, and the 

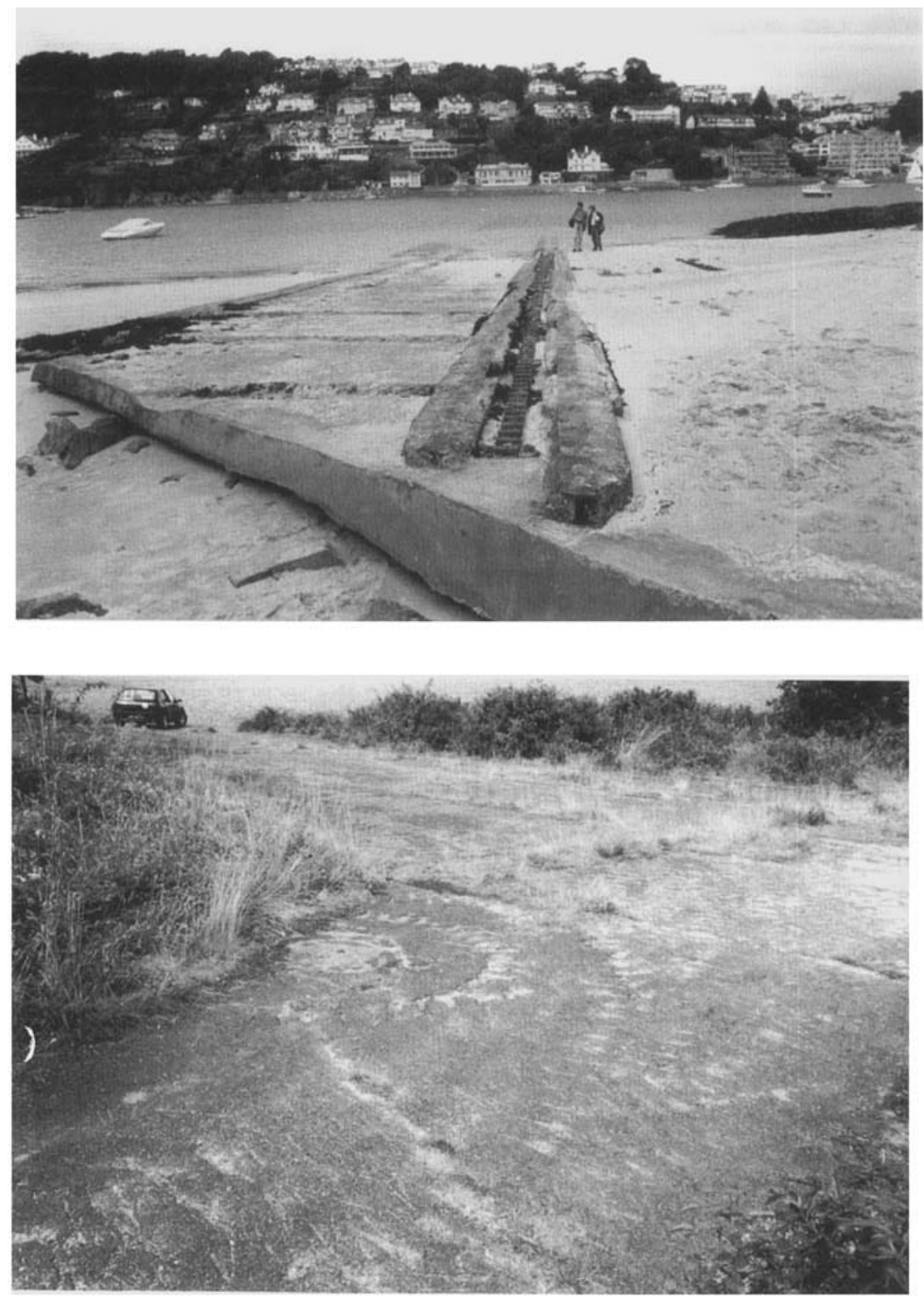

FIGURE 2. Slipway at Mill Bay, near Salcombe, Devon, seen at low tide. (Photo J. Schofield.)

FIGURE 3. A moment in time: detail of the LST hard at Turnaware, Cornwall, showing what might be contemporary vehicle tracks on the road surface. (Photo I. Schofield.)

extension to that group built to serve Operation Neptune. The list is complete in both these respects though, as photographs show, embarkation also took place at other sites not built for the purpose.

Embarkation sites were either modified docks, quays or harbours (such as Southampton Docks) or were constructed specifically for the purpose. Two main types of loading facility were used: LCT hards for 'landing craft, troops' and LST hards for 'landing ship, tanks'. Although LST hards were the most numerous, the two types were broadly similar. Each had: a concrete apron (solid concrete above high water, and flexible concrete matting below), and a series of dolphins; hutting for offices, workshops and stores; fuelling facilities; electric lighting and roads and transit areas (see Dobinson 1996: 14-18 for details). Survival tends to be confined to those hards built specifically for 
FIGURE 4. The slipways at Torquay, Torbay. (Photo I. Schofield.)

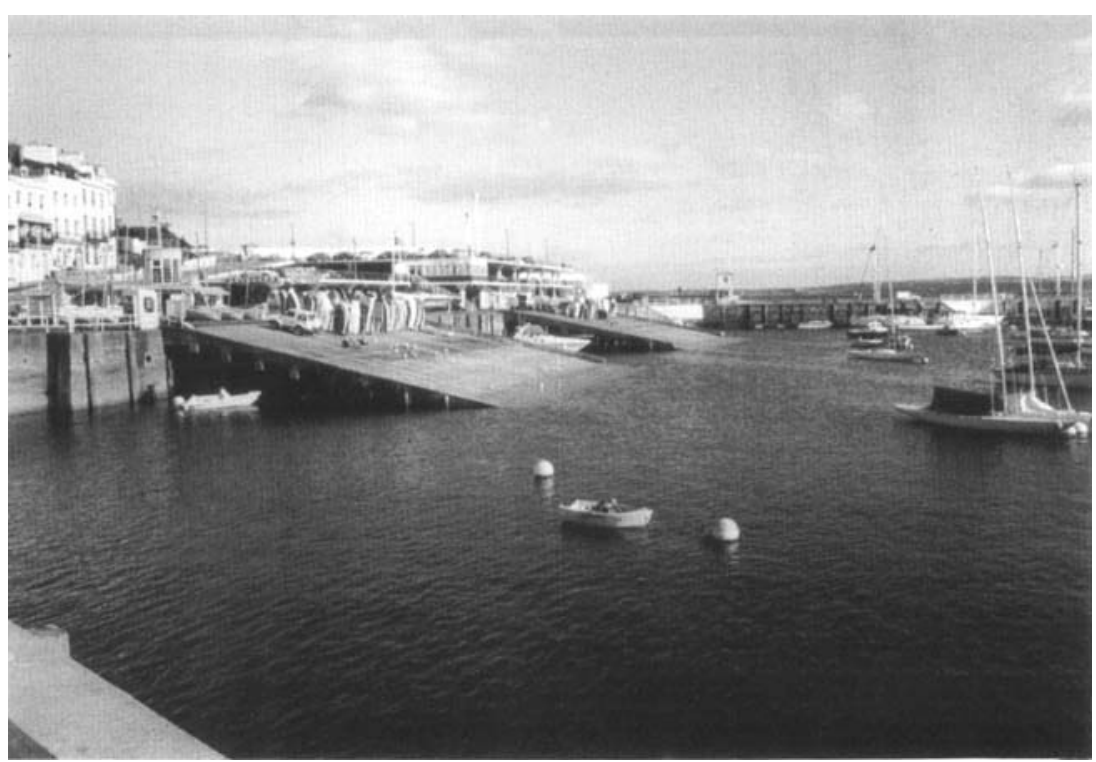

plex and extensive system of pipelines and terminals, with pumping stations at Dungeness (Kent) and Sandown and Shanklin on the Isle of Wight (see Searle 1995 for details). Although the pipelines were cleared from the seabed after the War, short sections do survive, particularly off the Isle of Wight. A pipeline valve survives at the Hamble oil refinery in Hampshire, while at the SOLO terminal at Thorness Bay on the Isle of Wight, shore-end pipe connections are exposed at low tide (Searle 1995: 84).

Unsurprisingly, little will survive of the many camps occupied prior to embarkation. What does survive, however, are the sources which reveal their locations and the effect of this encampment on the contemporary landscape. Aerial photographs by the United States Air Force (March 1944) for the Truro area show the hundreds of bell tents occupied by US troops concentrated along arterial routes (Johnson pers. comm.). Contemporary maps and plans, and ground photographs, show the overall layout and the character of these sites (see various photos in Doughty 1994). Along the minor roads linking Lepe with the New Forest, extended lay-bys date from this period while contemporary photos show vehicles using them, parked up under the trees. Finally, many of the fuel dumps, hutted camps and hospitals do survive, though often now as developed sites: industrial estates, modern hospitals and garages. 


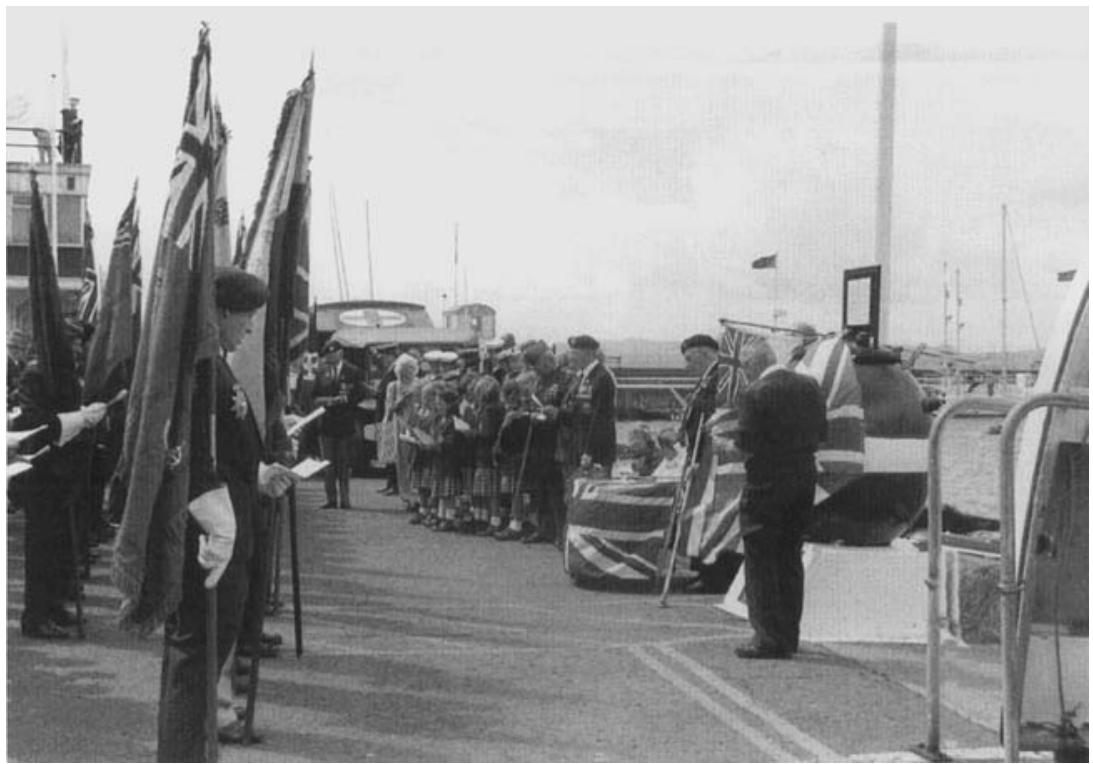

FIGURE 5.

Normandy veterans and local schoolchildren at the D-Day commemoration service at Torquay, June 6 2000. The slipways can be seen on the right of the picture, and contemporary vehicles in the background (Photo John Salvatore.)

\section{The future}

In terms of the three principal aspects of the Operation, therefore, significant archaeological remains do survive. While the view that static defences will survive better than materiel representing a mobile offensive may be valid in general terms (Wills 1994), sufficient remains of the preparations for D-Day in southern England to give an impression of the scale of the Operation, and the variety of the specific tasks involved. For these reasons (discussed more fully in Schofield forthcoming), D-Day sites have an international significance, alongside the battlefields of Normandy, in representing the physical manifestation of arguably the most significant military event in European - perhaps even world - history. Therefore sites in England will be considered for statutory protection where:

- surviving remains constitute a particularly rare example of a structure or component;

- sites survive in close proximity displaying the intensity and scale of the Operation, as witnessed at a local level;

- the range of components present combines with a degree of visual integrity to provide for a full interpretation of the site and how it functioned;

- the site displays a high quality of surviving remains; the size of the site is indicative of the scale of the Operation; and this can be appreciated in a physical setting which has changed little over the last 5060 years.

Those sites afforded protection will provide a significant cultural resource for the benefit of this and future generations. The events in Torquay on June 62000 (FIGURE 5) demonstrate the validity of this approach, and the need to retain such sites as touchstones for reasons of education, sense of place, commemoration and remembrance. As one veteran said after the commemoration service, and after hearing news of the Torquay slipways' protection: 'The listing is terrific news - [they] are just about the only thing left to tell future generations about what went on at the time.

Acknowledgements. This paper originated in archivesbased work by Colin Dobinson, but also owes much to a series of consultations with local authority staff in Devon, Cornwall, Hampshire and Essex, and subsequent field visits. I am grateful to the following for providing advice, and assisting with field visits: Dave Hooley and John Salvatore (English Heritage), Veronica Fiorato (previously Torbay Council), Antony Firth (Wessex Archaeology), Lt Col Frankland (17 Port and Maritime Regiment, Marchwood), Dave Hopkins (Hampshire County Council), Bill Horner (Devon County Council), Nicholas Johnson (Cornwall County Council), Dick Jury and William Foot (Defence of Britain Database and Archive), Fred Nash (Essex County Councí]) and Martin Watt (previously Exeter Archaeology). I am grateful to Colin Dobinson, Antony Firth and Nicholas Johnson for comments on an earlier draft. 
References

CunNingham, C. 1994. The Beaulieu River goes to war. Brockenhurst: Montagu Ventures.

DOBINSON, C. 1996. Twentieth century fortifications in England 5: Operation Overlord: embarkation works for the invasion of occupied Europe, 1942-44. York: CBA/English Heritage.

2000. Fields of deception: Britain's bombing decoys of WWII. London: Methuen.

DOBINSON, G., J. LAKE, J. \& A.J. SCHOFIELD. 1997. Monuments of War: defining England's 20th-century defence heritage, Antiquity 71: 288-99.

DoUchtY, M. (ed.). 1994. Hampshire and D-Day. Hampshire Books.

FRANCIS, P. 1997. United States Naval Amphibious Supply Base Exeter. Airfield Research Publishing.

HARRIS, A. 1994. Gathering mulberries, History Today (June 1994): 15-22

HUGHES, M. 1994. D-Day archaeology, in Doughty (ed.): 162-8.

MCDONALD, K. 1989. Dive Sussex. Underwater World Publications.
1994. Dive Kent. Underwater World Publications.

Murch, M., D. Murch \& L. Fairweather. 1984. The American Forces at Salcombe and Slapton during World War Two. Plymouth: PDS Printers.

PECKHAM, I. 1994. Southampton and D-Day. Southampton: Southampton City Council.

PRITCHARD, M. \& K. MCDONALD. 1991. Dive Wight and Hampshire. Underwater World Publications.

SCHOFIELD, J. Forthcoming. Monuments and the memories of war: motivations for preserving military sites in England, in J. Schofield, W.G. Johnson \& C. Beck (ed.), Matériel Culture: the archaeology of Twentieth Century Conflict. London: Routledge. One World Archaeology.

SEARLE, A. 1995. PLUTO: Pipe-Line Under The Ocean. Shanklin: Shanklin Chine.

WATT, M. Forthcoming. An archaeological evaluation at Mylor Cornwall.

WILLS, H. 1994. Archaeological aspects of D-Day: Operation Overlord, Antiquity 68: 843-5

\title{
Archaeobotanical evidence for early date consumption on Dalma Island, United Arab Emirates
}

\author{
Mark BeEch \& Elizabeth ShePherd*
}

The discovery of carbonized date stones in the United Arab Emirates has made a contribution to the dating of early date consumption in the Near East.

Key-words: dates, Phoenix dactylifera, chronology, subsistence, Near East

\section{Introduction}

Recent archaeological excavations carried out on Dalma island, located in the southwestern part of the Arabian Gulf some $45 \mathrm{~km}$ off the coast of Abu Dhabi in the United Arab Emirates (FIGURE 1), have revealed exciting new evidence for the early harvesting and consumption of dates (Phoenix dactylifera). Work carried out at the site (DA11) between 1992 and 1994 as part of the Abu Dhabi Islands Archaeological Survey established the presence of an early Neolithic beach settlement with structures and middens (Flavin \& Shepherd 1994). Small quantities of imported painted 'Ubaid ware from southern Mesopotamia were recovered, along with a large assemblage of what appear to be locally made gypsum plaster vessels. Many thousands of flint flakes and numerous tools (including drills, arrowheads, scrapers and tile knives) were found, as well as nearly a hundred ornamental beads and pendants of varying type. Food debris took the form of marine mollusca and animal remains, including a substantial assemblage of fish bones. Sondages excavated on the site in 1998 on the basis of earlier work revealed important further traces of the settlement, confirming the presence of at least two roundhouse-like structures with surviving post-holes and floors (Beech \& Elders 1999; Elders \& Beech 1998).

Radiocarbon dating of the Dalma date stones During the excavation in 1998 of a burnt layer or possible hearth (context 15, first identified in 1993), located about $25 \mathrm{~cm}$ above the floor level of one of the structures, several interesting archaeobotanical finds were made. These were a complete carbonized date stone as well as two fragments of burnt mud-brick which had

* Beech, Department of Archaeology, University of York, The King's Manor, York YO1 7EP, England. mjb117@york.ac.uk Shepherd, Norfolk Archaeological Unit, Garsett House, St Andrews Hall Plain, Norwich NR3 1AU, England. liz.shepherd.mus@norfolk.gov.uk

Received May 2000 accepted 27 July 2000 , revised 16 November 2000

ANTIQUITY 75 (2001): 83-9 